\title{
Improving Essential Oil Compositions of Purple Coneflower (Echinacea Purpurea L.) Medicinal Plant Using Novel Growing Media and Nutrition Pattern in Hydroponics
}

\author{
Fatemeh Ahmadi \\ Urmia University \\ Abbas Samadi ( $\sim$ asamadi2@gmail.com ) \\ Urmia University \\ Ebrahim Sepehr \\ Urmia University \\ Amir Rahimi \\ Urmia University \\ Sergey Shabala \\ University of Tasmania
}

\section{Research Article}

Keywords: Ammonium, Echinacea, Hydroponics, Perlite size, Secondary metabolites

Posted Date: January 15th, 2021

DOl: https://doi.org/10.21203/rs.3.rs-146246/v1

License: (c) (1) This work is licensed under a Creative Commons Attribution 4.0 International License.

Read Full License

Version of Record: A version of this preprint was published at Scientific Reports on April 13th, 2021. See the published version at https://doi.org/10.1038/s41598-021-87391-9. 


\section{Abstract}

Medicinal plants represent a valuable commodity due to beneficial effects of their natural products on human health, prompting a need for finding a way to optimize/increase their production. In this study, a novel growing media with various perlite particle size and its mixture with peat moss was tested for hydroponic-based production of Echinacea purpurea medicinal plant under greenhouse conditions. The plant growth parameters such as plant height, total fresh leave weight, fresh root weight, total biomass, total chlorophyll, leaf area, and essential oil compositions were assessed. Perlite particle size in the growing media was varied from very coarse (more than $2 \mathrm{~mm}$ ) to very fine (less than $0.5 \mathrm{~mm}$ ), and the ratio between perlite and peat moss varied from $50: 50 \mathrm{v} / \mathrm{v}$ to $30: 70 \mathrm{v} / \mathrm{v}$. In addition, two $\mathrm{NO}_{3}{ }^{-} / \mathrm{NH}_{4}{ }^{+}$ratios (90:10 and 70:30) were tested for each growing media. The medium containing very fine-grade perlite and 50:50 v/v perlite to peat moss ratio was found to be most optimal and beneficial for $E$. purpurea performance, resulting in maximal plant height, fresh and dry weight, leaf surface area, and chlorophyll content. It was also found that an increase in $\mathrm{NO}_{3}{ }^{-} / \mathrm{NH}_{4}{ }^{+}$ratio caused a significant increase in plant growth parameters and increase the plant essential oil content. The major terpene hydrocarbons found in extract of $E$. purpurea with the best growth parameters were germacrene D $(51 \%)$, myrcene $(15 \%)$, apinene (12\%), $\beta$-caryophyllene (11\%), and 1-Pentadecene (4.4\%), respectively. The percentages of these terpene hydrocarbons were increased by increasing of $\mathrm{NO}_{3}{ }^{-} / \mathrm{NH}_{4}{ }^{+}$ratio. It can be concluded that decreasing the perlite particle size and increasing the $\mathrm{NO}_{3}{ }^{-} / \mathrm{NH}_{4}{ }^{+}$ratio increased the plant growth parameters and essential oil compositions in E. purpurea.

\section{Introduction}

Medicinal plants and their beneficial effects on human health are well known in various cultures for centuries (Waidyanatha et al., 2020). Echinacea is a medicinal plant that belongs to the family of Asteracea/Compositae and is native to much of the United States (Ahmadi et al., 2020). The most popular species of the plant in medicine are E. purpurea, E. angustifolia, and E. pallida. The species has a black and pungent root and purple coneshape flowering head (Ahmadi et al., 2020). All parts of the $E$. purpurea species, especially root and coneflower, are rich in useful medicinal compounds, prompting significant attention of researchers to this species (Senica et al., 2019).

Using of E. purpurea essential oil in medicinal, cosmetic, and food industries is common in all over the world (Maggini et al., 2019). The effect of E. purpurea essential oils on antimicrobial properties has been proven in previous studies (Balciunaite et al., 2020). Also accepted is the role of some constituents of the essential oil of $E$. purpurea, including a-phellandrene, myrcene, limonene, a-pinene, $\beta$-pinene a, $\delta$ cadinene, germacrene $D$, and $\beta$-caryophllyene, as antifungal, antiviral and antibacterial agents (SharifiRad et al., 2018). Extracts of essential oil obtained from E. purpurea are efficient in pest control and could regulate insect population at different life stages (Clifford et al., 2002). Numerous studies have been focused on prominent insecticidal influence of $E$. purpurea essential oil compositions and found the better influence of them in comparing with chemicals or a potential source of insecticides (Clifford et al., 
2002). The antibacterial activity of E.purpurea essential oil is also reported against different food pathogens and bacteria in food industry (Indras et al., 2020).

While the industrial application of E. purpurea essential oils is well established, several factors such as weather changes, plant growth stage (Mousavi et al., 2019), and method of cultivation may influence both the composition and production of E. purpurea essential oil (Letchamo et al., 2002). Of specific interest is a cultivation method. The open field cultivation of E. purpurea has some significant limitations such as crop inconsistency, seed dormancy (Karg et al., 2019), water stress regims (Darvizheh et al., 2019), microbes, heavy metal ions and other pollutants (Ahmadi et al., 2020) and loss of wild germplasm, that affect the different chemical composition of the plant extract. The above limitations have prompted a shift towards plant production under greenhouse conditions, especially in hydroponic (or soilless) culture systems (Zheng et al., 2006). Growing in a greenhouse also offer an additional advantages of more effective control of plant nutrition (Russo et al., 2019).

Different hydroponic cultivation methods, such as artificial substrate media, water culture, and nutrient film techniques have been reported for E. purpurea cultivation (Zheng et al., 2006). However, using artificial substrates in the hydroponic cultivation system reduces the cost of establishing advanced hydroponic cultivation systems and also enables the farmer to make a practical use of it by using commonly raw materials such as cocopeat, sand, and vermiculite as an initial plant growing media (Samadi, 2011). Nevertheless, different inorganic products such as peat moss, perlite, mixed materials, etc. are fully or partially used instead of initial substrates due to their useful physical properties. The particle size of substrates is a critical factor in air and water-holding capacity, root distribution, and plant growth, which are different based on their origin and preparation conditions. A high volume of roots can concentrate at the top portion of the container includes low aeration and high water-holding capacity (Samadi, 2011).

In addition to the importance of substrates properties in the hydroponic culture system, attention to the chemical composition of nutrient solution is required (Samadi, 2011). Of specific interest is a source of nitrogen for plant cultivation. It has been reported that using a mixture of $\mathrm{NO}_{3}{ }^{-}$and $\mathrm{NH}_{4}{ }^{+}$can increase the leaf area, root distribution, total biomass, and plant growth parameters in comparison with each for nitrogen alone (Demirci et al., 2020). Previous researches also demonstrated that the $\mathrm{NO}_{3}{ }^{-} / \mathrm{NH}_{4}{ }^{+}$ratio could affect the plant root/ shoot ratio (Zheng et al., 2006). The plant species and environmental conditions are two critical factors that affect the optimum $\mathrm{NO}_{3}{ }^{-} / \mathrm{NH}_{4}{ }^{+}$ratio (Zaushintsena et al., 2019).

Although many researches have been performed on hydroponic culture of $E$. purpurea, but the use of culture media with different perlite particle sizes, different $\mathrm{NO}_{3}{ }^{-} / \mathrm{NH}_{4}{ }^{+}$ratios, and their effects on the phytochemical properties of $E$. purpurea has been assessed for the first time in this study. So the main goal of this study was to investigate the growth parameters and essential oil compositions of E. purpurea growing in new culture media in a hydroponic cultivation system with various perlite size and different $\mathrm{NO}_{3}{ }^{-} / \mathrm{NH}_{4}{ }^{+}$ratios. 


\section{Materials And Methods}

\subsection{Growth conditions}

The experiment was performed in a commercial greenhouse at Urmia University, West Azerbaijan, Iran. The air temperature was $22 / 18^{\circ} \mathrm{C}$ (day/night) and the humidity ranged from 70 to $80 \%$. The maximum photosynthetic photon flux density (PPFD) fluctuated from 550 to $750 \mu \mathrm{mol} / \mathrm{m}^{2} \mathrm{~s}$ inside the greenhouse.

The E. purpurea seeds were purchased from Iranian private joint-stock company, Pakan Bazr Esfahan (www. Pakanbazr.com). The seeds were sowed in plastic cups filled with a mixture of perlite and peat moss substrates as a medium to initiate germination. Irrigation was performed based on greenhouse conditions regularly. Seedlings (with four real leaves) were translocated to experimental plastic pots (2.5 L) containing a different ratios of perlite and peat moss as artificial substrates ( $100 \%$ perlite, $100 \%$ peat moss, $50 \%(\mathrm{v})$ perlite $+50 \%(\mathrm{v})$ peat moss, $70 \%(\mathrm{v})$ perlite $+30 \%(\mathrm{v})$ peat moss) with various perlite particle size containing less than $0.5 \mathrm{~mm}, 0.5-1 \mathrm{~mm}, 1-1.5 \mathrm{~mm}, 1.5-2 \mathrm{~mm}$, and more than $2 \mathrm{~mm}$. Chemical concentrations of nutrient solution are shown in Table 1. The $\mathrm{pH}$ and electrical conductivity (EC) of the nutrient solution were maintained between 5.7 to 6.2 and 1.0 to $1.5 \mathrm{dS} / \mathrm{m}$, respectively. According to the stage of the plant growth, 0.5 to $3.5 \mathrm{~L} /$ day was used in fertigation system (Zheng et al., 2006).

\subsection{Sample preparation}

Plants were harvested at the end of the flowering stage (eight months). The plants were divided into roots, stems, flower heads, and lower and upper leaves after washing with tap water. Root, flower heads, and leaves samples were dried at $25 \pm 1^{\circ} \mathrm{C}$, ground into a fine powder and collected for phytochemical analysis (Senica et al., 2019).

\subsection{Plant growth parameters}

The main growth parameters such as plant height $(\mathrm{cm})$, fresh root weight $(\mathrm{g} / \mathrm{plant})$, total fresh leave weight ( $\mathrm{g} /$ plant), total biomass $(\mathrm{g} / \mathrm{plant})$, and leaf area $\left(\mathrm{cm}^{2}\right)$ were determined for each plant at the matured stage. The leaf area was measured by using leaf area meter (model AccuPAR LP-80). Chlorophylls $a$ and $b$ were determined using $0.5 \mathrm{~g}$ of dry sample, which was homogenized with $10 \mathrm{~mL}$ acetone. Homogenized samples were centrifuged (Gyrozen ${ }^{\circledR}$, South Korea) at $10000 \times \mathrm{g}$ for $15 \mathrm{~min}$ at $4^{\circ} \mathrm{C}$ (Ahmadi et al., 2020). The supernatant was separated, and the absorbance spectra were measured at $400-700 \mathrm{~nm}$. The total chlorophyll was calculated at $645 \mathrm{~nm}$ and $663 \mathrm{~nm}$ respectively. So that (Arnon, 1949):

$C=20.2 A_{645^{-}}-2.350 A_{663}(1)$

Where $C$ is the total chlorophyll contents in $\mathrm{mg} / \mathrm{L}$ of acetone extract, $A_{645}$, and $A_{663}$ are the absorption of the extract at 645 and $663 \mathrm{~nm}$.

\subsection{Extraction of essential oils}


The E. purpurea plants which shown the best morphological properties (maximum height, dry and wet weight of leaves and roots, and leaf area) were selected for analysis of essential oil. Distilled water was added to $20 \mathrm{~g}$ powder samples (flower heads at the matured stage, leave, and root) at a 1:10 $(\mathrm{g} / \mathrm{mL}$ ) ratio. The essential oil was extract based on the distillation procedure using a commercial Clevenger apparatus (Kaya et al., 2019).

\subsection{Analysis of essential oil}

The essential oil analysis was performed using gas chromatography (GC, Shimadzu 9A) with $30 \mathrm{~m} \times 0.25$ $\mathrm{mm}$ capillary column coated with FFAP $0.25 \mu \mathrm{m}$ film; carrier gas, helium $(\mathrm{He})$ with a flow rate of $32 \mathrm{~cm} / \mathrm{s}$; injector temperature of $260^{\circ} \mathrm{C}$ and injection volume $0.2 \mu \mathrm{L}$. The programming was carried out from $90^{\circ} \mathrm{C}$ for $2 \mathrm{~min}$ rising at $7^{\circ} \mathrm{C} / \mathrm{min}$ to $180^{\circ} \mathrm{C}$, at $15^{\circ} \mathrm{C} / \mathrm{min}$ to $220^{\circ} \mathrm{C}$. Identifications of different components were made by library search program on monoterpenoids and sesquiterpenoids mass spectral database and by comparing RRT with those of reference samples (Kaya et al., 2019).

\subsection{Gas Chromatography-Mass Spectrometry}

GC-MS spectra were recorded on a Varian-3400 model fitted with a fused silica capillary column (30 m $\times$ $0.25 \mathrm{~mm}$ i.d.) coated with $0.25 \mu \mathrm{m}$ film. The $\mathrm{GC}$ was run from $60-250^{\circ} \mathrm{C}$ at a programmed rate of $8^{\circ} \mathrm{C}$ $/ \mathrm{min}$, hold at $100^{\circ} \mathrm{C}$ for $2 \mathrm{~min}$, using $\mathrm{He}$ as the carrier gas at a pressure of $1.6 \mathrm{~kg} / \mathrm{cm}^{2}$ and injector temperature of $250^{\circ} \mathrm{C}$. The GC column was coupled directly to the quadrupole mass spectrometer operated in the electron impact (EI) mode at $70 \mathrm{eV}$. Mass spectra were recorded at a scan speed of 9 at $\mathrm{m} / \mathrm{z} 700-10$.

\subsection{Statistical Analysis}

The statistics was based on the factorial with completely randomize design with three replications. The factors contained different sizes of perlite, including very coarse perlite (more than $2 \mathrm{~mm}$ ), coarse perlite (1.5-2 $\mathrm{mm})$, medium perlite $(1-1.5 \mathrm{~mm})$, fine perlite $(0.5-1 \mathrm{~mm})$, and very fine perlite (less than $0.5 \mathrm{~mm})$, two $\mathrm{NO}_{3}{ }^{-} / \mathrm{NH}_{4}{ }^{+}$rations (90:10 and 70:30), and a mixture of peat moss with different size of perlite at $50: 50 \mathrm{v} / \mathrm{v}$ and $30: 70 \mathrm{v} / \mathrm{v}$ peat moss to perlite ratios and pure peat moss ( $100 \%$ by volume). Data were analyzed using Duncan's multiple range tests at $P \leq 0.01$, using SAS (Version 9.4; SAS Institute, 2011) statistical program.

\section{Results And Discussion}

\subsection{Plant growth parameters}

Plant growth parameters of E. purpurea under different culture media and $\mathrm{NO}_{3}{ }^{-} / \mathrm{NH}_{4}{ }^{+}$ratios at the full flowering stage are shown in Table 2 and Figures 1 to 3 . Overall, plants grown in the $50 \%$ perlite $+50 \%$ peat moss medium with perlite particle size less than $0.5 \mathrm{~mm}$ and $90: 10 \mathrm{NO}_{3}{ }^{-} / \mathrm{NH}_{4}{ }^{+}$ratio had the highest height (mean $105 \mathrm{~cm}$ ) (Figure 1), fresh leave weight (mean $30 \mathrm{~g} /$ plant), fresh root weight (mean 65 
$\mathrm{g}$ /plant) (Figure 2), total biomass (mean $96 \mathrm{~g} /$ plant), and leaf area (mean $60 \mathrm{~cm}^{2}$ ) (Figure 3). Decreasing perlite percentage of culture media and perlite particle size improved all the morphological properties (Table 2). There were significant differences in the plant morphological properties at different $\mathrm{NO}_{3}{ }^{-} / \mathrm{NH}_{4}{ }^{+}$ ratios. Increasing nitrate $\left(\mathrm{NO}_{3}{ }^{-}\right)$proportion in the nitrogen nutrition of $E$. purpurea caused to increase in plant height and root weight considerably (Table 2).

The $\mathrm{pH}$ of growing media in recirculating systems is influenced by the $\mathrm{NO}_{3}{ }^{-} / \mathrm{NH}_{4}{ }^{+}$ratio (Zheng et al., 2006). It found that an increase of $\mathrm{NO}_{3}{ }^{-} / \mathrm{NH}_{4}{ }^{+}$ratio leads to significant increase of $E$. purpurea phytochemical properties due to improving root growth and root/shoot ratio (Russo et al., 2019).

Based on open hydroponic cultivation system in the present experiment, decreasing perlite particle size, increased the retention time of nutrient solution in the culture media. Increasing nutrient accessibility for plant roots by increasing retention time improves nutrient uptake and plant growth. However, the pure perlite culture system ( $100 \%$ perlite, $<0.5 \mathrm{~mm}$ ) has a very low air-filled porosity (AFP) of $33 \%$ and water holding capacity (WHC) of $56 \%$ in comparison with other fine-perlite culture media (Table 3 ). Accordingly, the lowest growth parameters were obtained in pure perlite medium (Table 2), which can be attributed to the rapid withdrawal of nutrient solution from the culture medium and the inability of the medium to maintain the nutrient solution. Due to the high porosity of peat mass and nutrient solution retention capability, an increase of the plant morphological parameters is expected in the presence of peat moss in various cultural media (Table 2). The noticeable increase in chlorophyll content by reducing perlite particle size implies the significant effect of culture media on photosynthesizing pigments (Table 2). It has been reported that the application of nitrogen fertilizers in the fine perlite culture media increased $\mathrm{N}$ content of the plants, thereby increasing their chlorophyll content, subsequently, and their ability to absorb sunlight and produce photosynthates, which resulted in their higher leaf area, and growth and yield (Coelho et al., 2020).

\subsection{Essential oil analysis}

The flower head, leaves, and root essential oil compositions of E. purpurea grown at the $50 \%$ perlite $+50 \%$ peat moss medium with perlite particle size less than $0.5 \mathrm{~mm}$ growing medium at different $\mathrm{NO}_{3}{ }^{-} / \mathrm{NH}_{4}{ }^{+}$ ratios (90:10 and 70:30) are shown in Tables 3 and 4, respectively. The essential oils were separated into 51 components, 38 of them were identified, comprising $92.8 \%$ of the total essential oil yield (Tables 3 and 4).

The content and composition of the essential oil exhibited a variable pattern at different plant organs at different $\mathrm{NO}_{3} / \mathrm{NH}_{4}{ }^{+}$ratios (Tables 4 and 5). The essential oil was characterized by a higher percentage of terpene hydrocarbons, especially the monoterpenoids, which constituted 60 to $70 \%$ of the essential oil composition. The major terpene hydrocarbons found are a-pinene, myrcene, $\beta$-caryophyllene, 1 Pentadecene, and germacrene $\mathrm{D}$. The percentages of these terpene hydrocarbons were higher in flower head than leave and root at both $\mathrm{NO}_{3}{ }^{-} / \mathrm{NH}_{4}{ }^{+}$ratios. The most abundant terpene found in the essential oil 
was germacrene $D$, which showed a remarkable rise from $1.5 \%$ in root to $51 \%$ in flower head and $0.95 \%$ in root to $47 \%$ in flower head at $90: 10$ and $70: 30 \mathrm{NO}_{3}{ }^{-} / \mathrm{NH}_{4}{ }^{+}$ratios, respectively. Variability was also obtained in the concentration of other compositions. The results (Tables 4 and 5 ) indicate that the various components of the essential oil of E. purpurea are specific to the plant organs, which influence their concentration.

The variations in the concentrations of various essential oil compositions at different $\mathrm{NO}_{3}{ }^{-} / \mathrm{NH}_{4}{ }^{+}$ratios (Tables 4 and 5) may be due to supply different amounts of $\mathrm{N}^{-\mathrm{NO}_{3}}{ }^{-}$to the plant. The presence of nitrogen as a key factor can affect the production of essential oils in aromatic plants (Oniszczuk et al., 2019). Nitrogen is critical factor in biosynthesis pathway of essential oil in medicinal and aromatic plants (Baričevič and Zupančič, 2002). Nitrogen increases photosynthetic efficiency and plays an important role in increasing the amount of essential oil by increasing the number and area of leave and providing a suitable condition for receiving sunlight energy and also participating in the structure of chlorophyll and enzymes involved in photosynthetic carbon metabolism (Hosseinpour et al., 2020). Nitrogen is an essential nutrient in plants used to synthesize many organic compounds in plants such as nucleic acids, enzymes, proteins, and amino acids, which are necessary for essential oil biosynthesis pathway (Banica et al., 2020). Besides, essential oils are terpenoids compounds whose constituent units (isonoids) such as isopentenyl pyrophosphate and dimethyl ally pyrophosphate are strongly formed into ATP and NADPH, and due to the effect of nitrogen in the production of these compounds, the amount of essential oil increased (Sitarek et al., 2017). Nitrogen increases the essential oil content of plants by increasing the dry weight (Nyalambisa et al., 2016). Comparing of the results in Tables 4 and 5 indicated that increase of $\mathrm{NO}_{3}{ }^{-}$concentration could increase the percentage of essential oil composition due to its effect on essential oil biosynthesis as demonstrated in previous researches (Diraz et al., 2012).

Germacrene $D$, myrcene, $a$-Pinene, $\beta$-Caryophyllene, and 1-Pentadecene were the major compositions of essential oil of E.purpurea grown in very fine-grade $(<0.5 \mathrm{~mm})$ perlite with $50: 50 \mathrm{v} / \mathrm{v}$ perlite to peat moss ratio (Tables 4 and 5). The compositions have a valuable beneficial effects in medicine and agriculture industries (Maggini et al., 2019).

Germacrene $D$ is a natural hydrocarbon, belongs to sesquiterpenes, which is found in aromatic plants (Kaya et al., 2019). The hydrocarbon is a useful bioactive phytochemical compound in human health Maintains healthy blood pressure is one of the important roles of germacrene compounds in humans (Balciunaite et al., 2020). The antimicrobial properties of germacrene $D$ were reported in previous researches (Sharifi-Rad et al., 2018). Anti-inflammatory, antimicrobial, and antioxidant effects of germacrene $D$ are also well known (Balciunaite et al., 2020). The anti-insect influence of germacrene $D$ has been reported in previous studies (Sharifi-Rad et al., 2018).

Myrcene is a terpene with anti-inflammatory and anti-depressant effects (Mousavi et al., 2019). Regulating the efficiency of other terpenes and cannabinoids by increasing of myrcene is recognized previously (Maggini et al., 2019). 
Pinene has a several of potential benefits, including anti-inflammatory, antimicrobial, antitumor, antioxidant, and neuroprotective effects. It may also help counteract the short-term memory issues that many people experience. Beta-caryophyllene is also known for antioxidant and anti-inflammatory medicinal effects. It is especially useful to decrease pain and anxiety (Holla et al., 2005).

The most abundant terpenes including, germacrene $D$, myrcene, $a$-Pinene, $\beta$-caryophyllene, and 1pentadecene were found in chemical composition of E. purpurea extract by previous researchers. Comparing of the results in present study with other researches shows the noticeable increase in essential oil composition by using novel growing media and nutrition pattern (Table 6), which is related to improve physical properties of growing media ( $50 \%$ perlite $+50 \%$ peat moss medium with perlite particle size less than $0.5 \mathrm{~mm}$ and $90: 10 \mathrm{NO}_{3}{ }^{-} / \mathrm{NH}_{4}{ }^{+}$ratio).

\section{Conclusion}

Effects of perlite particle size and its mixture with peat moss $(\mathrm{v} / \mathrm{v})$ at different $\mathrm{NO}_{3}{ }^{-} / \mathrm{NH}_{4}{ }^{+}$on growth parameters and essential oil compositions of hydroponically-grown E. purpurea were investigated. The results showed that the mixture of peat moss into very fine-grade perlite $(<0.5 \mathrm{~mm})$ with $50: 50 \mathrm{v} / \mathrm{v}$ perlite to peat moss ratio had a significant increase in plant growth parameters. It found that an increase of $\mathrm{NO}_{3}{ }^{-} / \mathrm{NH}_{4}{ }^{+}$ratio caused a significant increase in plant growth parameters. The percentages of these terpene hydrocarbons were increased by increasing of $\mathrm{NO}_{3}{ }^{-} / \mathrm{NH}_{4}{ }^{+}$ratio. Using of perlite and peat moss mixture for plant cultivation not only affects its growth parameters and phytochemical properties, but also reduces production costs in hydroponic systems.

\section{Declarations}

\section{Acknowledgment}

The authors are thankful to Mr. Yahya Hasirchi to collaborate on the experiment and the Office of Vice Chancellor for Research and Technology, Urmia University.

\section{Funding}

This research did not receive any specific grant from funding agencies in the public, commercial, or notfor-profit sectors.

\section{Declarations of interest}

The authors declare that they have no conflict of interest.

\section{References}


1. Ahmadi, F., Samadi, A., Rahimi, A., 2020. Improving growth properties and phytochemical compounds of Echinacea purpurea (L.) medicinal plant using novel nitrogen slow release fertilizer under greenhouse conditions. Scientific Reports. 10 (1), 1-11.

2. Arnon, D. I., 1949. Copper enzymes in isolated chloroplasts. Polyphennoloxidase in Beta vulgaris. Plant Physiology. 24 (1), 1-15.

3. Balciunaite, G., Haimi, P. J., Mikniene, Z., Savickas, G., Ragazinskiene, O., Juodziukyniene, N., Pangonyte, D., 2020. Identification of Echinacea Purpurea (L.) Moench root LysM Lectin with nephrotoxic properties. Toxins. 12 (2), 88-95.

4. Banica, F., Bungau, S., Tit, D. M., Behl, T., Otrisal, P., Nechifor, A. C., Nemeth, S., 2020. Determination of the total polyphenols content and antioxidant activity of Echinacea purpurea extracts using newly manufactured glassy carbon electrodes modified with carbon nanotubes. Journal of Manufacturing Processes. 8 (7), 833-840.

5. Baričevič, D., Zupančič, A. (2002). The impact of drought stress and/or nitrogen fertilization in some medicinal plants. Journal of Herbs, Spices \& Medicinal Plants, 9 (2-3), 53-64.

6. Coelho, J., Barros, L., Dias, M. I., Finimundy, T. C., Amaral, J. S., Alves, M. J., Ferreira, I. C., 2020. Echinacea purpurea (L.) Moench: chemical characterization and bioactivity of its extracts and fractions. Pharmaceuticals. 13(6), 125-132.

7. Clifford, L. J., Nair, M. G., Rana, J., Dewitt, D. L. (2002). Bioactivity of alkamides isolated from Echinacea purpurea (L.) Moench. Phytomedicine, 9 (3), 249-253.

8. Darvizheh, H., Zahedi, M., Abbaszadeh, B., Razmjoo, J., 2019. Changes in some antioxidant enzymes and physiological indices of purple coneflower (Echinacea purpurea) in response to water deficit and foliar application of salicylic acid and spermine under field condition. Scientia Horticulture. 247 (1), 390-399.

9. Demirci, T., Akçay, U. Ç., Baydar, N. G., 2020. Physical and biochemical differences in Agrobacterium rhizogenes-mediated transgenic hairy root lines of Echinacea purpurea. In Vitro Cellular and Developmental Biology Plant. 2 (1), 1-7.

10. Diraz, E., Karaman, S., Koca, N., 2012. Fatty Acıd and Essentıal Oil Compositıon of Echınacea Purpurea (L.) Moench, Growıng in Kahramanmaras-Turkey. Plant Biotechnology Reports. 2 (5), 101119.

11. Hosseinpour, M., Ebadi, A., Habibi, H., Nabizadeh, E., Jahanbakhsh, S., 2020. Enhancing enzymatic and nonenzymatic response of Echinacea purpurea by exogenous 24-epibrassinolide under drought stress. Industrial Crops and Products. 146 (1), 112045.

12. Holla, M., Vaverkova, S., Farkas, P., Tekel, J., 2005. Content of essential oil obtained from flower heads of Echinacea purpurea and identification of selected components. Herba Polonica, 3 (51), 225234.

13. Hudaib, M., Cavrini, V., Bellardi, M. G., Rubies-Autonell, C., 2002. Characterization of the essential oils of healthy and virus infected Echinacea purpurea (L.) Moench Plants. Journal of Essential Oil Research. 14 (6), 427-430. 
14. Indras, D. M., Marek, C. B., Penteado, A. J., Ferreira, F. S., Silva, F. C., Itinose, A. M., 2020. Evaluation of the toxic effects of the bottled medicine (garrafada) containing the Echinacea purpurea, Annona muricata, Tabebuia avellanedae, Pterodon emarginatus and Uncaria tomentosa in rats. Journal of Medicinal Plants Research. 14 (3), 105-117.

15. Kan, Y., Kartal, M., Ucan, U. S., Gulpinar, A. R., Kan, R., 2008. Antimicrobial activity and composition of the essential oils of Echinacea species cultivated under organic farming conditions in Turkey. Planta Medical Science, $74(9), 110-119$.

16. Karg, C. A., Wang, P., Vollmar, A. M., Moser, S., 2019. Re-opening the stage for Echinacea researchcharacterization of phylloxanthobilins as a novel anti-oxidative compound class in Echinacea purpurea. Phytomedicine. 60 (2), 152969.

17. Kaya, M., Merdivan, M., Tashakkori, P., Erdem, P., Anderson, J. L., 2019 Analysis of Echinacea flower volatile constituents by HS-SPME-GC/MS using laboratory-prepared and commercial SPME fibers. Journal of Essential Oil Research. 31 (2), 91-98.

18. Kyslychenko, A. A., Dyakonova, Y. V., Alexandrov, A. N., 2008. Gas chromatography with massspectrometric detection of the components of the essential oils from Achillea carpatica Blocki ex Dubovik and Echinacea pallidaHerbal Polemical Science, 4 (54), 62-67.

19. Letchamo, W., Polydeonny, L. V., Gladisheva, N. O., Arnason, T. J., Livesey, J., Awang, D. V. C. (2002). Factors affecting EchinaceaTrends in New Crops and New Uses, 514-521.

20. Maggini, V., Bandeira Reidel, R. V., De Leo, M., Mengoni, A., Rosaria Gallo, E., Miceli, E., Pistelli, L., 2020. Volatile profile of Echinacea purpurea plants after in vitro endophyte infection. Natural Product Research. 34 (15), 2232-2237.

21. Mousavi, S., Asadi-Sanam, S., Pezhmanmehr, M., 2019. Changes in morpho-physiological characteristics and the leaf and flower essential oils yield of coneflower [Echinacea purpurea (L.) Moench] with sodium nitroprusside (SNP) foliar application under drought stress. Iranian Journal of Horticultural Science. 50 (2), 375-391.

22. Nyalambisa, M., Oyemitan, I. A., Matewu, R., Oyedeji, O. O., Oluwafemi, O. S., Songca, S. P., Oyedeji, A. 0., 2017. Volatile constituents and biological activities of the leaf and root of Echinacea species from South Africa. Saudi Pharmaceutical Journal. 25 (3), 381-386.

23. Oniszczuk, T., Oniszczuk, A., Gondek, E., Guz, L., Puk, K., Kocira, A., Wójtowicz, A., 2019. Active polyphenolic compounds, nutrient contents and antioxidant capacity of extruded fish feed containing purple coneflower (Echinacea purpurea (L.) Moench.). Saudian Journal of Biological Science. 26 (1), 24-30.

24. Russo, D., Faraone, I., Labanca, F., Sinisgalli, C., Bartolo, M., Andrade, P. B., Milella, L., 2019. Comparison of different green-extraction techniques and determination of the phytochemical profile and antioxidant activity of Echinacea angustifolia extracts. Phytochemical Analysis. 30 (5), 547-555.

25. Samadi, A., 2011. Effect of the particle size distribution of perlite and its mixture with organic substrates on cucumber in the hydroponics system. Journal of Agriculture Science and Technology. $13(1), 121-129$. 
26. Senica, M., Mlinsek, G., Veberic, R., Mikulic-Petkovsek, M., 2019. Which plant part of purple coneflower (Echinacea purpurea (L.) Moench) should be used for tea and which for tincture?. Journal of Medicinal Food. 22 (1), 102-108.

27. Sharifi-Rad, M., Mnayer, D., Morais-Braga, M. F. B., Carneiro, J. N. P., Bezerra, C. F., Coutinho, H. D. M., Uribe, Y. A. H., 2018. Echinacea plants as antioxidant and antibacterial agents: from traditional medicine to biotechnological applications. Phytotherapy Research. 32 (9), 1653-1663.

28. Sitarek, P., Rijo, P., Garcia, C., Skała, E., Kalemba, D., Białas, A. J., Śliwiński, T., 2017. Antibacterial, antiinflammatory, antioxidant, and antiproliferative properties of essential oils from hairy and normal roots of Leonurus sibiricus and their chemical composition. Food Chemistry and Toxicology. 2 (1), 14-21.

29. Thappa, R. K., Bakshi, S. K., Dhar, P. L., Agarwal, S. G., Kitchlu, S., Kaul, M. K., Suri, K. A., 2004. Significance of changed climatic factors on essential oil composition of Echinacea purpurea under subtropical conditions. Flavour and Fragrance Journal. 19 (5), 452-454.

30. Waidyanatha, S., Pierfelice, J., Cristy, T., Mutlu, E., Burback, B., Rider, C. V., Ryan, K., 2020. A strategy for test article selection and phytochemical characterization of Echinacea purpurea extract for safety testing. Food Chemistry and Toxicology. 121 (6), 111125.

31. Zaushintsena, A. V., Milentyeva, I. S., Babich, O. O., Kiseleva, T. F., Popova, D. G., Bakin, I. A., Lukin, A. A., 2019. Quantitative and qualitative profile of biologically active substances extracted from purple echinacea (Echinacea Purpurea) growing in the Kemerovo region: functional foods application. Foods and Raw Materials. 7 (1), 135-143.

32. Zheng, Y., Dixon, M., Saxena, P., 2006. Greenhouse production of Echinacea purpurea (L.) and angustifolia using different growing media, $\mathrm{NO}_{3}{ }^{-} / \mathrm{NH}_{4}{ }^{+}$ratios, and watering regimes. Canadian Journal of Plant Science. 86 (3), 809-815.

\section{Tables}

Table 1. Chemical properties of nutrient solution 


\begin{tabular}{|lll|}
\hline Attribute & Fertilizer type & Element \\
\hline 15 & $\left(\mathrm{NH}_{4}\right)_{2} \mathrm{SO}_{4}-\mathrm{KNO}_{3}-\mathrm{Ca}\left(\mathrm{NO}_{3}\right)_{2}$ & $\mathrm{~N}(\mathrm{mM})$ \\
\hline 1 & $\mathrm{H}_{3} \mathrm{PO}_{3}$ & $\mathrm{P}(\mathrm{mM})$ \\
\hline 4 & $\mathrm{KNO}_{3}$ & $\mathrm{~K}(\mathrm{mM})$ \\
\hline 2 & $\mathrm{Ca}\left(\mathrm{NO}_{3}\right)_{2}$ & $\mathrm{Ca}(\mathrm{mM})$ \\
\hline 2 & $\mathrm{MgSO}_{4} \cdot 7 \mathrm{H}_{2} \mathrm{O}$ & $\mathrm{Mg}(\mathrm{mM})$ \\
\hline 50 & $\mathrm{Sulfate} \mathrm{fertilizers}$ & $\mathrm{S}(\mathrm{mM})$ \\
\hline 9 & $\mathrm{Fe}^{-\mathrm{EDTA}_{\mathrm{S}}}$ & $\mathrm{Fe}(\mu \mathrm{M})$ \\
\hline 0.3 & $\mathrm{CuSO}_{4} \cdot 5 \mathrm{H}_{2} \mathrm{O}$ & $\mathrm{Mn}(\mu \mathrm{M})$ \\
\hline 0.8 & $\mathrm{ZnSO}_{4} \cdot 7 \mathrm{H}_{2} \mathrm{O}$ & $\mathrm{Cu}(\mu \mathrm{M})$ \\
\hline 15 & $\mathrm{H}_{3} \mathrm{BO}_{3}$ & $\mathrm{Zn}(\mu \mathrm{M})$ \\
\hline 0.11 & $\mathrm{H}_{24} \mathrm{Mo}_{7} \mathrm{~N}_{6} \mathrm{O}_{24} \cdot 4 \mathrm{H}_{2} \mathrm{O}$ & $\mathrm{B}(\mu \mathrm{M})$ \\
\hline
\end{tabular}

Table 2. Some morphological properties of $E$. purpurea growing on various culture media and $\mathrm{NO}_{3}{ }^{-} / \mathrm{NH}_{4}{ }^{+}$ ratio at the flowering stage. 


\begin{tabular}{|c|c|c|c|c|c|c|c|}
\hline & & Height & $\begin{array}{l}\text { Total fresh } \\
\text { leave } \\
\text { weight }\end{array}$ & $\begin{array}{l}\text { Fresh } \\
\text { root } \\
\text { weight }\end{array}$ & $\begin{array}{l}\text { Total } \\
\text { biomass }\end{array}$ & $\begin{array}{l}\text { Total } \\
\text { Chlorophyll }\end{array}$ & $\begin{array}{l}\text { Leaf } \\
\text { area }\end{array}$ \\
\hline $\begin{array}{l}\text { Culture } \\
\text { media }\end{array}$ & $\begin{array}{l}\mathrm{NO}_{3}{ }^{-} / \mathrm{NH}_{4}{ }^{+} \\
\text {ratio }\end{array}$ & $(\mathrm{cm})$ & (g/plant) & (g/plant) & (g/plant) & $(\mathrm{mg} / \mathrm{g} \mathrm{FW})$ & $\left(\mathrm{cm}^{2}\right)$ \\
\hline \multirow{2}{*}{$\begin{array}{l}100 \% \mathrm{Pe} \\
(>2 \mathrm{~mm})\end{array}$} & $90: 10$ & $\begin{array}{l}5.3^{n} \pm \\
0.27^{-}\end{array}$ & $1.3 \pm 0.13$ & $\begin{array}{l}3.1^{\mathrm{s}} \pm \\
0.16^{-}\end{array}$ & $\begin{array}{l}4.4^{x} \pm \\
0.25^{ \pm}\end{array}$ & $5.12 \pm 0.11$ & $\begin{array}{l}5 \pm \\
0.41\end{array}$ \\
\hline & $70: 30$ & $\begin{array}{l}3.2^{n} \pm \\
0.21\end{array}$ & $1.5 \pm 0.11$ & $\begin{array}{l}3.1^{\mathrm{s}} \pm \\
0.11^{-}\end{array}$ & $\begin{array}{l}4.1^{x} \pm \\
0.14\end{array}$ & $\begin{array}{l}3.53 \pm \\
0.032\end{array}$ & $\begin{array}{l}4 \pm \\
0.35\end{array}$ \\
\hline \multirow[t]{2}{*}{$100 \% \mathrm{Pt}$} & $90: 10$ & $\begin{array}{l}55^{\mathrm{h}} \pm \\
2.9\end{array}$ & $10 \pm 2.1$ & $20^{p} \pm 3.9$ & $\begin{array}{l}30^{w} \pm \\
4.1\end{array}$ & $8.8 \pm 0.15$ & $\begin{array}{l}20 \pm \\
0.25\end{array}$ \\
\hline & 70:30 & $\begin{array}{l}47^{j \mathrm{k}} \pm \\
2.1\end{array}$ & $8.2 \pm 1.1$ & $16^{r} \pm 2.5$ & $24^{y} \pm 3.2$ & $6.6 \pm 0.12$ & $\begin{array}{l}15 \pm \\
0.14\end{array}$ \\
\hline \multirow[t]{2}{*}{$\begin{array}{l}50 \% \mathrm{Pt}+ \\
50 \% \operatorname{Pe}(<0.5 \\
\mathrm{mm})\end{array}$} & $90: 10$ & $\begin{array}{l}105^{a} \\
\pm 6.1\end{array}$ & $40 \pm 3.2$ & $75^{\mathrm{a}} \pm 4.6$ & $\begin{array}{l}116^{\mathrm{a}} \pm \\
7.1\end{array}$ & $18.5 \pm 0.11$ & $\begin{array}{l}60 \pm \\
0.35\end{array}$ \\
\hline & $70: 30$ & $\begin{array}{l}91^{d} \pm \\
4.2^{-}\end{array}$ & $28 \pm 1.2$ & $52^{d} \pm 3.2$ & $\begin{array}{l}80^{d} \pm \\
4.1\end{array}$ & $15.1 \pm 0.11$ & $\begin{array}{l}51 \pm \\
0.23\end{array}$ \\
\hline \multirow[t]{2}{*}{$\begin{array}{l}50 \% \mathrm{Pt}+ \\
50 \% \mathrm{Pe}(0.5- \\
1 \mathrm{~mm})\end{array}$} & $90: 10$ & $\begin{array}{l}98^{b} \pm \\
5.1\end{array}$ & $27 \pm 2.1$ & $53^{\mathrm{C}} \pm 4.1$ & $81^{c} \pm 6.1$ & $16.2 \pm 0.13$ & $\begin{array}{l}55 \pm \\
0.15\end{array}$ \\
\hline & $70: 30$ & $\begin{array}{l}71^{f} \pm \\
3.2^{-}\end{array}$ & $21 \pm 1.1$ & $48^{f} \pm 2.5$ & $70^{i} \pm 3.6$ & $13.2 \pm 0.11$ & $\begin{array}{l}49 \pm \\
0.11\end{array}$ \\
\hline \multirow{2}{*}{$\begin{array}{l}50 \% \mathrm{Pt}+ \\
50 \% \mathrm{Pe}(1- \\
1.5 \mathrm{~mm})\end{array}$} & $90: 10$ & $\begin{array}{l}96^{\mathrm{bc}} \pm \\
5.9\end{array}$ & $26 \pm 2.1$ & $50^{e} \pm 3.2$ & $76^{e} \pm 5.2$ & $14.6 \pm 0.16$ & $\begin{array}{l}50 \pm \\
0.15\end{array}$ \\
\hline & $70: 30$ & $\begin{array}{l}82^{\mathrm{e}} \pm \\
3.2\end{array}$ & $24 \pm 1.2$ & $43^{i} \pm 1.9$ & $\begin{array}{l}67^{\mathrm{jk}} \pm \\
2.4\end{array}$ & $12.8 \pm 0.11$ & $\begin{array}{l}42 \pm \\
0.10\end{array}$ \\
\hline \multirow[t]{2}{*}{$\begin{array}{l}50 \% \mathrm{Pt}+ \\
50 \% \mathrm{Pe}(1.5- \\
2 \mathrm{~mm})\end{array}$} & $90: 10$ & $\begin{array}{l}91^{d} \pm \\
4.3\end{array}$ & $25 \pm 1.1$ & $45^{h} \pm 2.5$ & $\begin{array}{l}71^{\mathrm{hi}} \pm \\
3.6\end{array}$ & $13.8 \pm 0.14$ & $\begin{array}{l}43 \pm \\
0.11\end{array}$ \\
\hline & $70: 30$ & $\begin{array}{l}71^{f} \pm \\
2.1^{-}\end{array}$ & $24 \pm 1.1$ & $40^{k} \pm 1.9$ & $\begin{array}{l}65^{1 \mathrm{~m}} \pm \\
2.4\end{array}$ & $12.2 \pm 0.12$ & $\begin{array}{l}38 \pm \\
0.11\end{array}$ \\
\hline \multirow{2}{*}{$\begin{array}{l}50 \% \mathrm{Pt}+ \\
50 \% \mathrm{Pe}(>2 \\
\mathrm{mm})\end{array}$} & $90: 10$ & $\begin{array}{l}85^{\mathrm{e}} \pm \\
3.3^{-}\end{array}$ & $23 \pm 2.1$ & $41^{\mathrm{jk}} \pm 2.5$ & $\begin{array}{l}64^{\mathrm{m}} \pm \\
4.1\end{array}$ & $13.2 \pm 0.12$ & $\begin{array}{l}40 \pm \\
0.14\end{array}$ \\
\hline & $70: 30$ & $\begin{array}{l}66^{9} \pm \\
2.5^{-1}\end{array}$ & $21 \pm 1.1$ & $37^{\prime} \pm 2.1$ & $\begin{array}{l}58^{p} \pm \\
3.5\end{array}$ & $11.5 \pm 0.11$ & $\begin{array}{l}32 \pm \\
0.10\end{array}$ \\
\hline
\end{tabular}

Pt: peat moss and Pe: perlite 
The numbers in the parentheses show perlite particle size

Each value is expressed as mean $\pm S D(n=3)$. Means bearing different letters in the same column are significantly different $(P \leq 0.01)$

The numbers show as mean \pm standard deviation

The interaction effect of different treatments on total fresh leave weight, chlorophylls a and $b$, and leaf area was not significant

Table 2. Continue

\begin{tabular}{|c|c|c|c|c|c|c|c|}
\hline & & Height & $\begin{array}{l}\text { Total fresh } \\
\text { leave } \\
\text { weight }\end{array}$ & $\begin{array}{l}\text { Fresh } \\
\text { root } \\
\text { weight }\end{array}$ & $\begin{array}{l}\text { Total } \\
\text { biomass }\end{array}$ & $\begin{array}{l}\text { Total } \\
\text { Chlorophyll }\end{array}$ & $\begin{array}{l}\text { Leaf } \\
\text { area }\end{array}$ \\
\hline $\begin{array}{l}\text { Culture } \\
\text { media }\end{array}$ & $\begin{array}{l}\mathrm{NO}_{3}{ }^{-} / \mathrm{NH}_{4}{ }^{+} \\
\text {ratio }\end{array}$ & $(\mathrm{cm})$ & (g/plant) & (g/plant) & (g/plant) & $(\mathrm{mg} / \mathrm{g} \mathrm{FW})$ & $\left(\mathrm{cm}^{2}\right)$ \\
\hline \multirow{2}{*}{$\begin{array}{l}30 \% \mathrm{Pt}+70 \% \\
\mathrm{Pe} \\
(<0.5 \mathrm{~mm})\end{array}$} & $90: 10$ & $\begin{array}{l}85.2^{\mathrm{e}} \\
\pm 2.8\end{array}$ & $23 \pm 1.1$ & $50^{e} \pm 3.1$ & $\begin{array}{l}74^{\mathrm{g}} \pm \\
4.1^{-1}\end{array}$ & $16.1 \pm 0.13$ & $\begin{array}{l}42 \pm \\
0.15\end{array}$ \\
\hline & $70: 30$ & $\begin{array}{l}71.6^{f} \\
\pm 2.1\end{array}$ & $22 \pm 1.1$ & $43^{i} \pm 2.4$ & $65^{\prime} \pm 3.6$ & $12.3 \pm 0.11$ & $\begin{array}{l}35 \pm \\
0.11\end{array}$ \\
\hline \multirow[t]{2}{*}{$\begin{array}{l}30 \% \mathrm{Pt}+70 \% \\
\mathrm{Pe}(0.5-1 \\
\mathrm{mm})\end{array}$} & $90: 10$ & $\begin{array}{l}71.1^{f} \\
\pm 3.5\end{array}$ & $21 \pm 1.3$ & $47^{g} \pm 2.2$ & $68^{\mathrm{j}} \pm 4.1$ & $13.5 \pm 0.12$ & $\begin{array}{l}38 \pm \\
0.15\end{array}$ \\
\hline & $70: 30$ & $\begin{array}{l}63.9^{9} \\
\pm 1.9\end{array}$ & $20 \pm 1.1$ & $37^{\prime} \pm 2.1$ & $\begin{array}{l}58^{p} \pm \\
3.1^{-1}\end{array}$ & $10.4 \pm 0.11$ & $\begin{array}{l}30 \pm \\
0.11\end{array}$ \\
\hline \multirow{2}{*}{$\begin{array}{l}30 \% \mathrm{Pt}+70 \% \\
\mathrm{Pe} \\
(1-1.5 \mathrm{~mm})\end{array}$} & $90: 10$ & $\begin{array}{l}66.1^{\mathrm{g}} \\
\pm 2.5\end{array}$ & $18.8 \pm 2.1$ & $42^{\mathrm{ij}} \pm 2.8$ & $\begin{array}{l}61^{\mathrm{no}} \pm \\
4.2\end{array}$ & $12.9 \pm 0.13$ & $\begin{array}{l}32 \pm \\
0.13\end{array}$ \\
\hline & $70: 30$ & $\begin{array}{l}52.7^{\mathrm{hi}} \\
\pm 2.1\end{array}$ & $15.4 \pm 1.3$ & $32^{n} \pm 1.6$ & $47^{s_{ \pm}} 2.6$ & $9.4 \pm 0.10$ & $\begin{array}{l}25 \pm \\
0.11\end{array}$ \\
\hline \multirow[t]{2}{*}{$\begin{array}{l}30 \% \mathrm{Pt}+70 \% \\
\mathrm{Pe}(1.5-2 \\
\mathrm{mm})\end{array}$} & $90: 10$ & $\begin{array}{l}55.5^{h} \\
\pm 3.2\end{array}$ & $18.6 \pm 1.2$ & $\begin{array}{l}34^{\mathrm{m}} \pm \\
2.5\end{array}$ & $53^{q} \pm 3.1$ & $11.3 \pm 0.14$ & $\begin{array}{l}28 \pm \\
0.13\end{array}$ \\
\hline & $70: 30$ & $\begin{array}{l}43.1^{\mathrm{kl}} \\
\pm 2.1\end{array}$ & $14.1 \pm 1.1$ & $29^{\circ} \pm 1.1$ & $\begin{array}{l}43^{\mathrm{tu}} \pm \\
2.1^{-}\end{array}$ & $8.4 \pm 0.11$ & $\begin{array}{l}23 \pm \\
0.11\end{array}$ \\
\hline \multirow{2}{*}{$\begin{array}{l}30 \% \mathrm{Pt}+70 \% \\
\mathrm{Pe} \\
(>2 \mathrm{~mm})\end{array}$} & $90: 10$ & $\begin{array}{l}49.3^{\mathrm{ij}} \\
\pm 4.2\end{array}$ & $15.9 \pm 2.5$ & $32^{n} \pm 2.1$ & $\begin{array}{l}48^{r s} \pm \\
3.6\end{array}$ & $10.4 \pm 0.13$ & $\begin{array}{l}25 \pm \\
0.14\end{array}$ \\
\hline & $70: 30$ & $\begin{array}{l}35.9^{\mathrm{m}} \\
\pm 2.1\end{array}$ & $12.7 \pm 1.3$ & $28^{\circ} \pm 1.5$ & $41^{v} \pm 2.2$ & $8.3 \pm 0.11$ & $\begin{array}{l}19 \pm \\
0.12\end{array}$ \\
\hline
\end{tabular}


Pt: peat moss and Pe: perlite

The numbers in the parentheses show perlite particle size

Each value is expressed as mean $\pm S D(n=3)$. Means bearing different letters in the same column are significantly different $(P \leq 0.01)$

The numbers show as mean \pm standard deviation

The interaction effect of different treatments on total fresh leave weight, chlorophylls a and b, and leaf area was not significant

Table 3. Physical properties of media used in greenhouse E. purpurea culture.

\begin{tabular}{|c|c|c|c|c|}
\hline & $\begin{array}{l}\text { Water holding } \\
\text { capacity }\end{array}$ & $\begin{array}{l}\text { Air-filled } \\
\text { porosity }\end{array}$ & $\begin{array}{l}\text { Bulk } \\
\text { density }\end{array}$ & $\begin{array}{l}\text { Total } \\
\text { porosity }\end{array}$ \\
\hline Culture media & (\% vol) & $(\%)$ & $\left(\mathrm{g} \mathrm{cm}^{-3}\right)$ & (\%) \\
\hline $100 \% \mathrm{Pe}(>2 \mathrm{~mm})$ & 56 & 33 & 0.16 & 89 \\
\hline $100 \% \mathrm{Pt}$ & 75 & 10 & 0.21 & 85 \\
\hline $\begin{array}{l}50 \% \mathrm{Pt}+50 \% \mathrm{Pe}(<0.5 \\
\mathrm{mm})\end{array}$ & 68 & 24 & 0.18 & 92 \\
\hline $\begin{array}{l}50 \% \mathrm{Pt}+50 \% \mathrm{Pe}(0.5-1 \\
\mathrm{mm})\end{array}$ & 65 & 26 & 0.18 & 91 \\
\hline $\begin{array}{l}50 \% \mathrm{Pt}+50 \% \mathrm{Pe}(1-1.5 \\
\mathrm{mm})\end{array}$ & 64 & 28 & 0.18 & 92 \\
\hline $\begin{array}{l}50 \% P t+50 \% \text { Pe }(1.5-2 \\
\mathrm{mm})\end{array}$ & 62 & 31 & 0.17 & 93 \\
\hline $50 \% \mathrm{Pt}+50 \% \mathrm{Pe}(>2 \mathrm{~mm})$ & 60 & 33 & 0.17 & 93 \\
\hline $\begin{array}{l}30 \% \mathrm{Pt}+70 \% \mathrm{Pe}(<0.5 \\
\mathrm{mm})\end{array}$ & 61 & 28 & 0.14 & 89 \\
\hline $\begin{array}{l}30 \% \mathrm{Pt}+70 \% \mathrm{Pe}(0.5-1 \\
\mathrm{mm})\end{array}$ & 58 & 30 & 0.14 & 88 \\
\hline $\begin{array}{l}30 \% \mathrm{Pt}+70 \% \mathrm{Pe}(1-1.5 \\
\mathrm{mm})\end{array}$ & 56 & 32 & 0.15 & 88 \\
\hline $\begin{array}{l}30 \% \mathrm{Pt}+70 \% \mathrm{Pe}(1.5-2 \\
\mathrm{mm})\end{array}$ & 53 & 33 & 0.15 & 86 \\
\hline $30 \% \mathrm{Pt}+70 \% \mathrm{Pe}(>2 \mathrm{~mm})$ & 50 & 35 & 0.16 & 85 \\
\hline
\end{tabular}


Pt: peat moss and Pe: perlite

The numbers in the parentheses show perlite particle size

Table 4. Essential oil chemical composition of E.purpurea grown at the best growing media at 90:10 $\mathrm{NO}_{3}{ }^{-} / \mathrm{NH}_{4}{ }^{+}$ratio 


\begin{tabular}{|c|c|c|c|c|c|}
\hline Components & Class $^{a}$ & $\mathrm{LRI}^{\mathrm{b}}$ & Percentage & & \\
\hline & & & flower heads & leaves & root \\
\hline Heptane & NT & 776 & 0.018 & 0.013 & $\operatorname{tr}^{\mathrm{c}}$ \\
\hline Myrcene & $\mathrm{MH}$ & 921 & 15 & 11 & 1.1 \\
\hline (Z)-3-Hexenol acetate & NT & 930 & 0.32 & 0.25 & 0.11 \\
\hline $\mathrm{n}$-Tridecene & NT & 940 & 0.028 & 0.012 & $\operatorname{tr}$ \\
\hline$\delta$-Elemene & $\mathrm{SH}$ & 965 & 0.12 & 0.097 & $\operatorname{tr}$ \\
\hline Cyclosativene & $\mathrm{SH}$ & 968 & 0.32 & 0.25 & 0.11 \\
\hline $\mathrm{a}-Y$ langene & $\mathrm{SH}$ & 983 & 0.19 & 0.13 & 0.12 \\
\hline a-Copaene & $\mathrm{SH}$ & 998 & 1.4 & 1.1 & 0.25 \\
\hline a-Pinene & $\mathrm{SH}$ & 1003 & 12 & 8.1 & 1.15 \\
\hline$\beta$-Bourbonene & $\mathrm{SH}$ & 1010 & 0.22 & 0.19 & 0.064 \\
\hline$\beta$-Cubebene & $\mathrm{SH}$ & 1018 & 0.19 & 0.17 & 0.013 \\
\hline$\beta$-Elemene & $\mathrm{SH}$ & 1020 & 0.33 & 0.24 & 0.072 \\
\hline n-Tetradecene & NT & 1022 & 0.96 & 0.52 & 0.15 \\
\hline$\beta$-Caryophyllene & $\mathrm{SH}$ & 1031 & 11 & 7.6 & 1.1 \\
\hline$\beta$-Copaene & $\mathrm{SH}$ & 1047 & 1.1 & 0.78 & 0.15 \\
\hline y-Elemene & $\mathrm{SH}$ & 1074 & 0.41 & 0.35 & $\operatorname{tr}$ \\
\hline trans-a-bergamotene & $\mathrm{SH}$ & 1362 & 0.78 & 0.43 & 0.096 \\
\hline Aromadendrene & $\mathrm{SH}$ & 1365 & 0.41 & 0.38 & $\operatorname{tr}$ \\
\hline a-Humulene & SHS & 1370 & 0.21 & 0.15 & $\operatorname{tr}$ \\
\hline cis-Muurola-4(14), 5- diene & $\mathrm{SH}$ & 1390 & 0.063 & 0.022 & $\operatorname{tr}$ \\
\hline (Z)-8-dodecen-1-ol & NT & 1391 & 0.014 & 0.027 & $\operatorname{tr}$ \\
\hline Germacrene D & $\mathrm{SH}$ & 1412 & 51 & 43 & 1.6 \\
\hline (E)-B-ionone & $\mathrm{AC}$ & 1422 & 0.28 & 0.21 & $\operatorname{tr}$ \\
\hline 1-Pentadecene & NT & 1430 & 4.4 & 2.1 & 0.91 \\
\hline Bicyclogermacrene & $\mathrm{SH}$ & 1441 & 0.66 & 0.46 & $\operatorname{tr}$ \\
\hline a-Muurolene & $\mathrm{SH}$ & 1468 & 1.2 & 0.89 & 0.031 \\
\hline n-Pentadecane & NT & 1476 & 0.58 & 0.38 & $\operatorname{tr}$ \\
\hline
\end{tabular}




\begin{tabular}{|c|c|c|c|c|c|}
\hline (Z)-a-Bisabolene & $\mathrm{SH}$ & 1479 & 0.43 & 0.35 & $\operatorname{tr}$ \\
\hline trans- $\beta$-Guaiene & $\mathrm{SH}$ & 1488 & 0.11 & 0.082 & $\operatorname{tr}$ \\
\hline$(E, E)$-a-Farnesene & $\mathrm{SH}$ & 1415 & 0.062 & 0.024 & $\operatorname{tr}$ \\
\hline a-Bulnesene & $\mathrm{SH}$ & 1520 & 0.14 & 0.097 & $\operatorname{tr}$ \\
\hline$\delta$-Amorphene & $\mathrm{SH}$ & 1548 & 0.19 & 0.85 & 0.053 \\
\hline trans- $\gamma$-Cadinene & $\mathrm{SH}$ & 1561 & 0.057 & 0.032 & $\operatorname{tr}$ \\
\hline$\delta$-Cadinene & $\mathrm{SH}$ & 1570 & 0.092 & 0.015 & $\operatorname{tr}$ \\
\hline Selina-3,7(11)-diene & $\mathrm{SH}$ & 1575 & 0.083 & 0.021 & $\operatorname{tr}$ \\
\hline Germacrene B & $\mathrm{SH}$ & 1620 & 0.054 & 0.013 & $\operatorname{tr}$ \\
\hline Germacrene D-4-ol & os & 1630 & 0.092 & 0.042 & $\operatorname{tr}$ \\
\hline Nerolidol acetate & os & 1662 & 0.063 & 0.011 & $\operatorname{tr}$ \\
\hline
\end{tabular}

a Class: AC, apocarotenoids; $\mathrm{MH}$, monoterpene hydrocarbons; SH, sesquiterpene hydrocarbons; NT, nonterpenes; OS, oxygenated sesquiterpenes; ${ }^{b}$ LRI, Linear Retention Index; ${ }^{c}$ trace (below $0.01 \%$ )

Table 5. Essential oil chemical composition of E.purpurea grown at the best growing media at 70:30 $\mathrm{NO}_{3}{ }^{-} / \mathrm{NH}_{4}{ }^{+}$ratio 


\begin{tabular}{|c|c|c|c|c|c|}
\hline Components & Class $^{a}$ & $\mathrm{LRI}^{\mathrm{b}}$ & Percentage & & \\
\hline & & & flower heads & leaves & root \\
\hline Heptane & NT & 776 & $\operatorname{tr}$ & $\operatorname{tr}$ & $\operatorname{tr}^{\mathrm{c}}$ \\
\hline Myrcene & $\mathrm{MH}$ & 921 & 10 & 8.9 & 0.75 \\
\hline (Z)-3-Hexenol acetate & NT & 930 & 0.21 & 0.11 & 0.083 \\
\hline $\mathrm{n}$-Tridecene & NT & 940 & $\operatorname{tr}$ & $\operatorname{tr}$ & $\operatorname{tr}$ \\
\hline$\delta$-Elemene & $\mathrm{SH}$ & 965 & 0.082 & 0.023 & $\operatorname{tr}$ \\
\hline Cyclosativene & $\mathrm{SH}$ & 968 & 0.21 & 0.15 & $\operatorname{tr}$ \\
\hline a-Ylangene & $\mathrm{SH}$ & 983 & 0.11 & 0.08 & 0.092 \\
\hline a-Copaene & $\mathrm{SH}$ & 998 & 0.89 & 0.66 & 0.11 \\
\hline a-Pinene & $\mathrm{SH}$ & 1003 & 8.5 & 6.1 & 0.75 \\
\hline$\beta$-Bourbonene & $\mathrm{SH}$ & 1010 & 0.15 & 0.091 & $\operatorname{tr}$ \\
\hline$\beta$-Cubebene & $\mathrm{SH}$ & 1018 & 0.12 & 0.024 & $\operatorname{tr}$ \\
\hline$\beta$-Elemene & $\mathrm{SH}$ & 1020 & 0.18 & 0.11 & 0.022 \\
\hline n-Tetradecene & NT & 1022 & 0.59 & 0.39 & $\operatorname{tr}$ \\
\hline$\beta$-Caryophyllene & $\mathrm{SH}$ & 1031 & 7.1 & 5.5 & 0.45 \\
\hline$\beta$-Copaene & $\mathrm{SH}$ & 1047 & 0.84 & 0.62 & 0.083 \\
\hline y-Elemene & $\mathrm{SH}$ & 1074 & 0.22 & 0.11 & $\operatorname{tr}$ \\
\hline trans-a-bergamotene & $\mathrm{SH}$ & 1362 & 0.54 & 0.42 & $\operatorname{tr}$ \\
\hline Aromadendrene & $\mathrm{SH}$ & 1365 & 0.21 & 0.15 & $\operatorname{tr}$ \\
\hline a-Humulene & SHS & 1370 & 0.13 & 0.053 & $\operatorname{tr}$ \\
\hline cis-Muurola-4(14), 5- diene & $\mathrm{SH}$ & 1390 & $\operatorname{tr}$ & $\operatorname{tr}$ & $\operatorname{tr}$ \\
\hline (Z)-8-dodecen-1-ol & NT & 1391 & $\operatorname{tr}$ & $\operatorname{tr}$ & $\operatorname{tr}$ \\
\hline Germacrene D & $\mathrm{SH}$ & 1412 & 47 & 33 & 0.95 \\
\hline (E)-B-ionone & $A C$ & 1422 & 0.15 & 0.042 & $\operatorname{tr}$ \\
\hline 1-Pentadecene & NT & 1430 & 3.1 & 1.8 & 0.25 \\
\hline Bicyclogermacrene & $\mathrm{SH}$ & 1441 & 0.25 & 0.16 & $\operatorname{tr}$ \\
\hline a-Muurolene & $\mathrm{SH}$ & 1468 & 0.87 & 0.64 & 0.034 \\
\hline n-Pentadecane & NT & 1476 & 0.18 & 0.091 & $\operatorname{tr}$ \\
\hline
\end{tabular}




\begin{tabular}{|c|c|c|c|c|c|}
\hline (Z)-a-Bisabolene & $\mathrm{SH}$ & 1479 & 0.23 & 0.15 & $\operatorname{tr}$ \\
\hline trans- $\beta$-Guaiene & $\mathrm{SH}$ & 1488 & 0.052 & 0.014 & $\operatorname{tr}$ \\
\hline$(\mathrm{E}, \mathrm{E})$ - $\mathrm{a}$-Farnesene & $\mathrm{SH}$ & 1415 & $\operatorname{tr}$ & $\operatorname{tr}$ & $\operatorname{tr}$ \\
\hline a-Bulnesene & $\mathrm{SH}$ & 1520 & 0.064 & 0.013 & $\operatorname{tr}$ \\
\hline ठ-Amorphene & $\mathrm{SH}$ & 1548 & 0.092 & 0.032 & $\operatorname{tr}$ \\
\hline trans- $\gamma$-Cadinene & $\mathrm{SH}$ & 1561 & $\operatorname{tr}$ & $\operatorname{tr}$ & $\operatorname{tr}$ \\
\hline$\delta$-Cadinene & $\mathrm{SH}$ & 1570 & 0.023 & 0.014 & $\operatorname{tr}$ \\
\hline Selina-3,7(11)-diene & $\mathrm{SH}$ & 1575 & $\operatorname{tr}$ & $\operatorname{tr}$ & $\operatorname{tr}$ \\
\hline Germacrene B & $\mathrm{SH}$ & 1620 & $\operatorname{tr}$ & $\operatorname{tr}$ & $\operatorname{tr}$ \\
\hline Germacrene D-4-ol & OS & 1630 & 0.017 & $\operatorname{tr}$ & $\operatorname{tr}$ \\
\hline Nerolidol acetate & os & 1662 & 0.019 & $\operatorname{tr}$ & $\operatorname{tr}$ \\
\hline
\end{tabular}

a Class: AC, apocarotenoids; $\mathrm{MH}$, monoterpene hydrocarbons; SH, sesquiterpene hydrocarbons; NT, nonterpenes; OS, oxygenated sesquiterpenes; ${ }^{b}$ LRI, Linear Retention Index; ${ }^{c}$ trace (below $0.01 \%$ )

Table 6. Maximum percentage of major essential oil compositions of E.purpurea reported in various previous studies

\begin{tabular}{|llllll|}
\hline & $\begin{array}{l}\text { Germacrene } \\
\text { D }\end{array}$ & Myrcene & $\begin{array}{l}\text { a- } \\
\text { Pinene }\end{array}$ & $\begin{array}{l}\text { 价 } \\
\text { Caryophyllene }\end{array}$ & $\begin{array}{l}\text { 1- } \\
\text { Pentadecene }\end{array}$ \\
\hline Present study & 51 & 15 & 12 & 11 & 4.4 \\
\hline Diraz et al., 2012 & 11 & - & - & 7.2 & - \\
\hline Sitarek et al., 2017 & 19 & 0.12 & 1.1 & - & 0.73 \\
\hline Thappa et al., 2003 & 33 & 10 & 6.6 & 9.3 & 2.5 \\
\hline Nyalambisa et al., 2016 & 20 & - & 3.7 & 4.5 & - \\
\hline $\begin{array}{l}\text { Hudaib and Cavrini, } \\
\text { 2002 }\end{array}$ & 29 & 1.7 & 2.3 & 3.1 & - \\
\hline Holla et al., 2005 & 4.8 & 2.1 & 5.1 & 3.6 & 2.5 \\
\hline Kyslychenko et al., 2008 & 25 & 11 & 7.5 & 5.2 & 2.9 \\
\hline Kan et al., 2008 & 32 & 9.4 & 4.2 & 4.3 & 3.2 \\
\hline
\end{tabular}




\section{Figures}
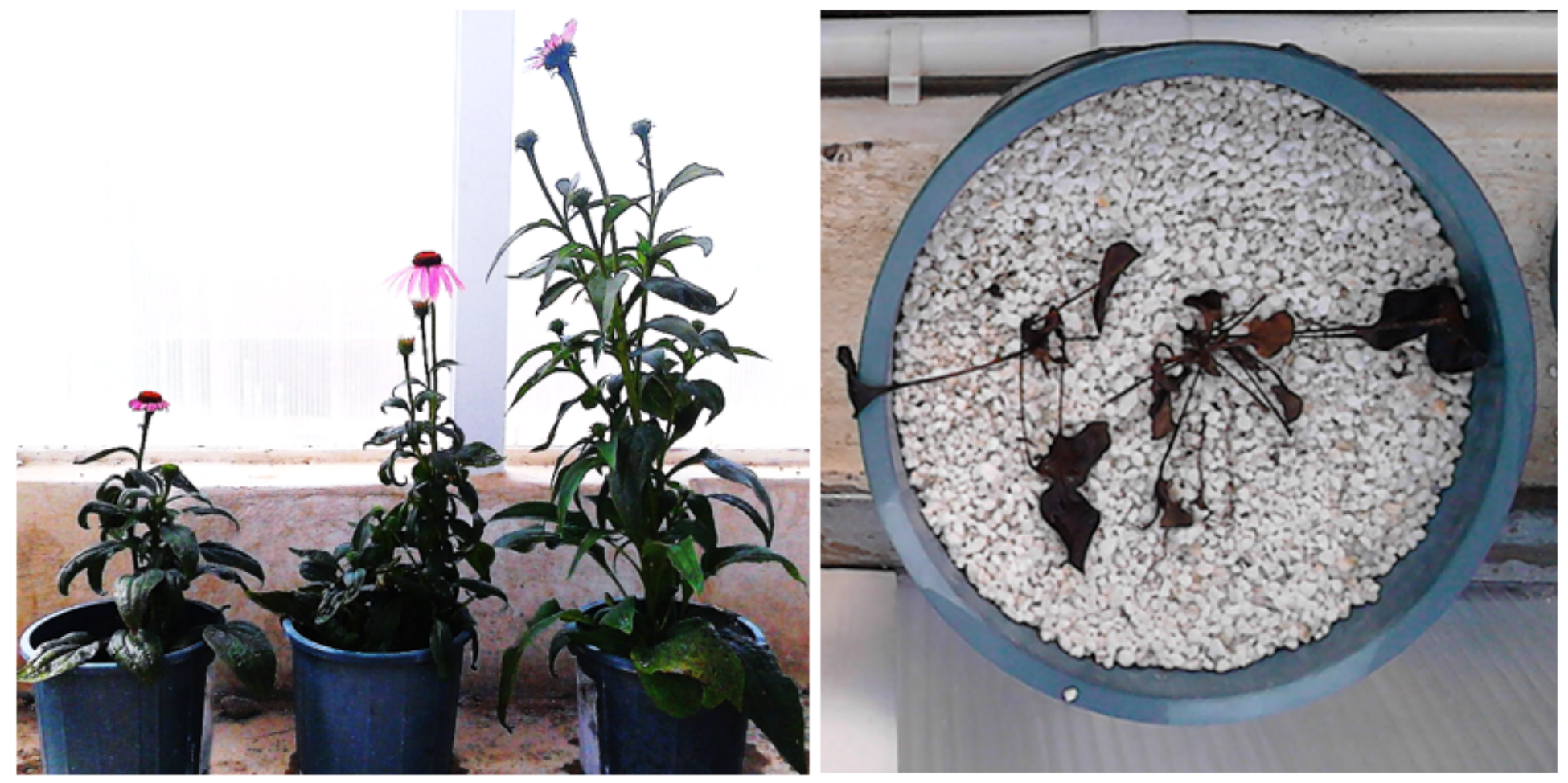

\section{Figure 1}

Echinacea purpurea grown in (A) $100 \%$ peat moss, (B) $30 \%$ peat moss $+70 \%$ perlite $(<0.5 \mathrm{~mm}),(\mathrm{C}) 50 \%$ peat moss $+50 \%$ perlite $(<0.5 \mathrm{~mm})$, (D) $100 \%$ perlite $(>2 \mathrm{~mm}$ ) culture media, just at $90: 10 \mathrm{NO3} / / \mathrm{NH} 4+$ ratio.
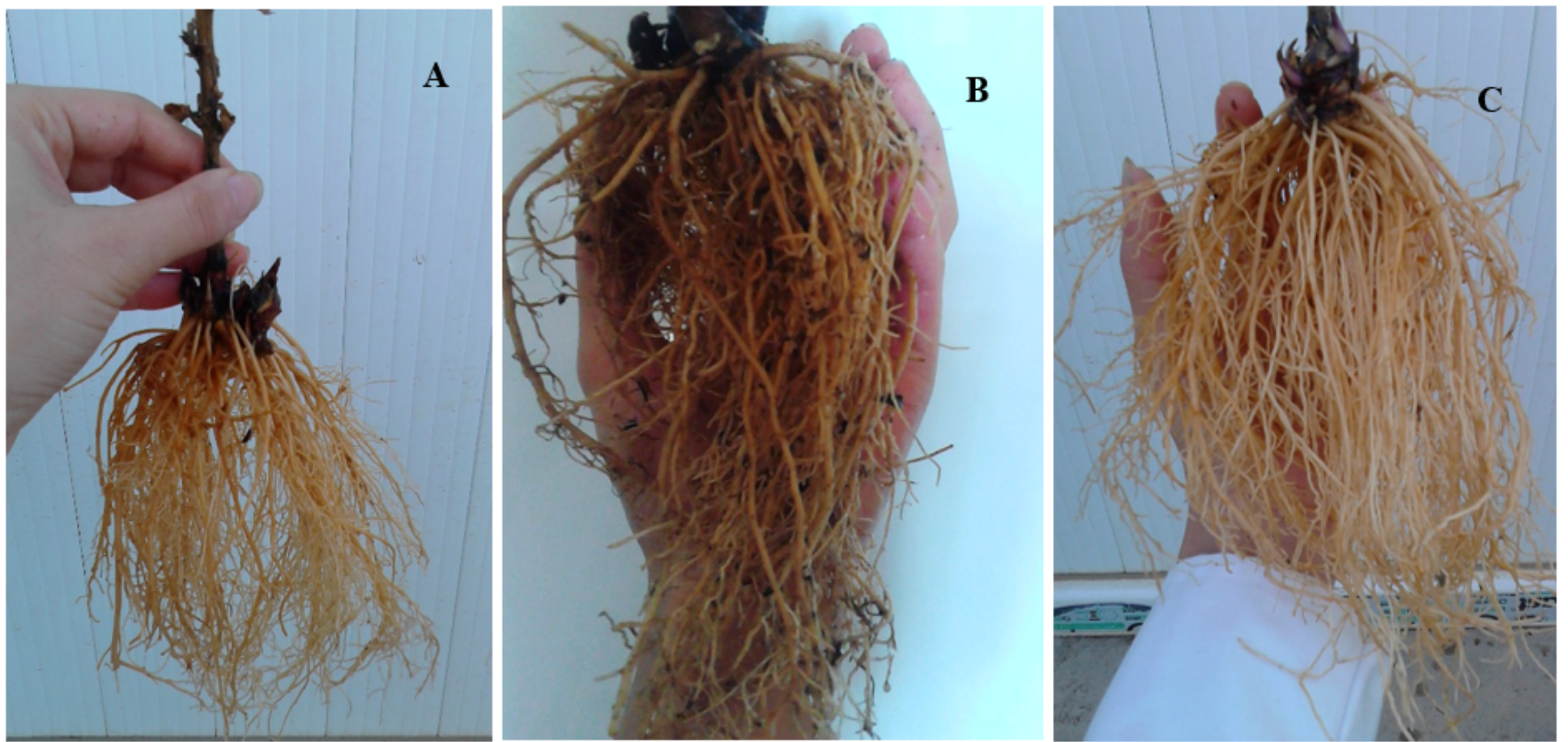

Figure 2 
Root morphology of E. purpurea grown in (A) $100 \%$ peat moss, (B) $30 \%$ peat moss $+70 \%$ perlite $(<0.5$ $\mathrm{mm}),(\mathrm{C}) 50 \%$ peat moss $+50 \%$ perlite $(<0.5 \mathrm{~mm})$ at $90: 10 \mathrm{NO}-/ \mathrm{NH} 4+$ ratio. The root of E. purpurea grown in $100 \%$ perlite was very small.
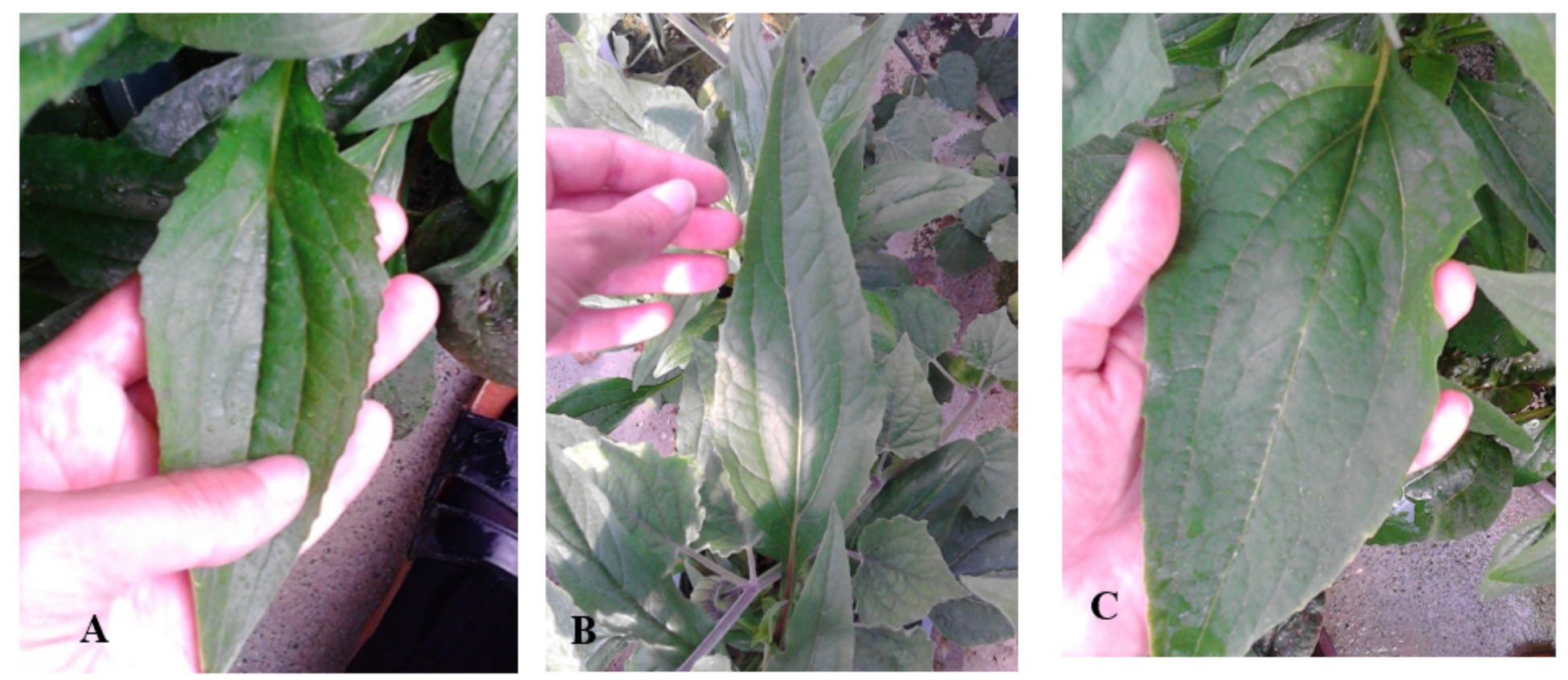

\section{Figure 3}

Leaf morphology of E. purpurea grown in (A) $100 \%$ peat moss, (B) $30 \%$ peat moss $+70 \%$ perlite $(<0.5$ $\mathrm{mm})$, (C) $50 \%$ peat moss $+50 \%$ perlite $(<0.5 \mathrm{~mm})$ at $90: 10 \mathrm{NO}-/ \mathrm{NH} 4+$ ratio. 